Georgetown University Law Center

Scholarship @ GEORGETOWN LAW

2017

\title{
A Destination-Based Cash Flow Tax Can Be Structured to Comply with World Trade Organization Rules
}

Itai Grinberg

Georgetown University Law Center, itai.grinberg@law.georgetown.edu

This paper can be downloaded free of charge from:

https://scholarship.law.georgetown.edu/facpub/2013

https://ssrn.com/abstract=3075494

70 Nat'I Tax J. 803-818 (2017)

This open-access article is brought to you by the Georgetown Law Library. Posted with permission of the author. Follow this and additional works at: https://scholarship.law.georgetown.edu/facpub

Part of the International Trade Law Commons, Law and Economics Commons, and the Tax Law Commons 


\title{
A DESTINATION-BASED CASH FLOW TAX CAN BE STRUCTURED TO COMPLY WITH WORLD TRADE ORGANIZATION RULES
}

\author{
Itai Grinberg
}

\begin{abstract}
This paper briefly outlines alternative approaches to enacting a destination-based cash flow tax that are more clearly compatible with the World Trade Organization rules than the approach that has previously been described in the literature. The first structural alternative involves expanding the universe of businesses subject to the tax by clearly defining both the base of the new U.S. business tax and its tax nexus requirement as domestic consumption, and thereafter treating foreign importers and other sellers equivalently, rather than imposing a deduction disallowance or an import tax. The second alternative involves adopting a business activities tax, and then enacting a business-level incentive for encouraging employment that is as a legal matter separate from the tax. Either approach avoids the key World Trade Organization concerns.
\end{abstract}

Keywords: cash flow tax, tax reform, WTO, destination-basis taxation, international economic law, trade law

JEL Codes: F5, $\mathrm{H2}, \mathrm{K} 3$

\section{INTRODUCTION}

he July 2016 House Republican Blueprint proposal to enact a destination-based cash flow tax (DBCFT), for the United States catalyzed a significant debate in the literature on many economic and legal features of such a tax. One of the most prominent legal debates revolves around whether a DBCFT can be compatible with the obligations most countries around the world, including the United States, have entered into as members of the World Trade Organization (WTO). Indeed, as the debate over a U.S. DBCFT heated up after the November 2016 elections, the European Union (EU) and other U.S. trading partners reportedly began putting together a legal challenge against the WTO-legality of a DBCFT. ${ }^{1}$

\footnotetext{
1 Donnan, Shawn, Barney Jopson, and Paul McClean, "EU and Others Gear Up for WTO Challenge to US Border Tax," Financial Times, February 13, 2017.
}

Itai Grinberg: Georgetown University Law Center, Washington, DC, USA (Itai.grinberg@law.georgetown. edu). The author served as Counsel to the 2005 President's Advisory Panel on Federal Tax Reform. 
The DBCFT as recently proposed by Auerbach et al. (2017) and the DBCFT portion of the Blueprint both strongly resemble the Growth and Investment Tax (GIT) proposal made in 2005 by President Bush's Advisory Panel on Federal Tax Reform (Tax Reform Panel). ${ }^{2}$ Indeed, several well-known commentators called the GIT "the Blueprint for the Blueprint." The GIT, like the Auerbach et al. proposal, provided for expensing for capital investments, denied interest deductions, and adopted border adjustments as well as "destination-basis" principles. The Tax Reform Panel report discussed the mechanism by which border adjustments could be implemented in significant detail. Both the Blueprint and the Auerbach et al. proposal generally track those details from the 2005 report. $^{3}$

Given the similarities between the Tax Reform Panel proposal, the Blueprint, and Auerbach et al. (2017), most analysts considering WTO issues in a DBCFT have come to assume that a DBCFT must use the implementation mechanisms for border adjustments described by the Tax Reform Panel in 2005. Resulting analyses of the WTO issues embedded in a DBCFT make two key assumptions. First, they assume that border adjustments will be achieved either by disallowing deductions for imports, ${ }^{4}$ or by imposing a withholding tax on imported goods and services. Second, they assume that wage support will be implemented via a deduction within the tax system itself, rather than a credit outside the formal parameters of the tax.

However, there are alternative approaches to developing a DBCFT that are more clearly WTO-compatible than the approach that has previously been described in the literature. This paper briefly outlines these alternatives. Section II describes the key WTO rules that affect a DBCFT, and how those rules create WTO concerns for DBCFTs as described in the GIT, the Blueprint, and Auerbach et al. (2017). Section IIIA describes how what I call the "Greenprint" avoids those WTO concerns. Section IIIB describes how what I call the "Jobs Credit Plan" avoids those same concerns. Section IV concludes with some general lessons for business tax reform.

\section{THE WTO AND BORDER ADJUSTMENTS}

The WTO comprises a series of agreements under which member countries abide by certain rules in regulating trade across national borders. These agreements impose rules on (1) restraints countries may place on imports from other countries and (2) sub-

2 Report of the President's Advisory Panel on Federal Tax Reform, Simple, Fair, and Pro-Growth: Proposals to Fix America's Tax System, November 2005, https://www.treasury.gov/resource-center/tax-policy/ Documents/Report-Fix-Tax-System-2005.pdf. The author served as Counsel to the Panel.

3 The Tax Reform Panel in turn based its GIT proposal on the X-tax, a cash flow consumption tax proposal developed over two decades by the late David Bradford. Bradford considered a destination-based version of the X-tax in The X-tax in the World Economy, an unfinished working paper he made public shortly before his untimely death (Bradford, 2003, pp. 6-10).

4 See, e.g., Pullmian, Susan, Sarah Nassauer, and Richard Rubin, "Retailers Risk Multibillion-Dollar Earnings Hit Under GOP Tax Plan," Wall Street Journal, January 6, 2017, https://www.wsj.com/articles/ retailers-risk-multibillion-dollar-earnings-hit-under-gop-tax-plan-1483698602. ("At the same time, the 'border-adjusted' portion of the proposal would impose taxes on imported goods by making imports a nondeductible expense, and exempt exports.") 
sidies they may provide for exports from their own country. The rules on imports and exports are distinct, and are not symmetric. As a result, meaningful analysis of WTO rules requires thinking about the WTO "disciplines" on imports and exports separately.

\section{A. Imports}

The concept of national treatment is the centerpiece of the WTO import regime. ${ }^{5}$ As part of the national treatment obligation, Article III of the General Agreement on Tariffs and Trade (GATT) provides that "internal taxes and other internal charges ... should not be applied to imported or domestic products so as to afford protection to domestic production." ${ }^{\prime 6}$ Under this rule the amount of tax a country formally levies on imports once those imports have cleared customs cannot exceed the amount of tax levied on the same good or service if produced domestically. This "national treatment" requirement is the key limitation the WTO imposes on the import side with respect to border-adjusting a tax. Article XVII of the General Agreement on Trade in Services (GATS) imposes a parallel although somewhat more limited national treatment obligation for trade in services.

The GIT's treatment of imports raised two national treatment concerns. ${ }^{7}$ First, purchases of certain imported products were treated as non-deductible, while purchases of like domestic products were deductible. Allowing a tax deduction for an internal tax for "domestic" products, while denying the deduction for purchases of like products from importers, appears to be a facial violation of the GATT Article III and GATS Article XVII commitments to national treatment. ${ }^{8}$

Alternatively, one might view deduction disallowance as a border charge rather than an internal tax. In that case, the deduction disallowance rule would be treated as a tariff on imports at the rate of the internal tax. Such a tariff would violate Article II of the GATT, which requires WTO member countries to charge no more in tariffs than is set forth in an agreed tariff schedule. ${ }^{9}$

\footnotetext{
5 General Agreement on Tariffs and Trade 1994 [hereinafter GATT] art. III, available at https://www.wto. org/english/res_e/booksp_e/analytic_index_e/gatt1994_02_e.htm\#article3. Article XVII of the General Agreement on Trade in Services imposes a parallel but somewhat more limited national treatment obligation for trade in services. General Agreement on Trade in Services art. XVII, 33 I.L.M. 1167, 1180 (1994).

${ }^{6}$ GATT art. III, available at https://www.wto.org/english/res_e/booksp_e/analytic_index_e/gatt1994_02_e. htm\#article3.

7 These same concerns arise under Auerbach et al. (2017), and would seem to arise in the Blueprint (although the Blueprint provides many fewer details and so proposed mechanisms of implementation are often less clear). For ease of exposition the remainder of the paper proceeds by treating the GIT as the reference system for conventional DBCFTs as heretofore described.

8 Note that similar treatment results whenever the VAT is implemented through a so-called "reverse charge" mechanism, so this concern may be overbroad.

9 Article II of GATT also provides that imports "shall also be exempt from all other duties or charges of any kind imposed on or in connection with [importation]." Article II:1(b). So every charge must in effect be classified as either an internal tax or a tariff. GATT art. III, available at https://www.wto.org/english/ res_e/booksp_e/analytic_index_e/gatt1994_02_e.htm\#article3.
} 
Second, certain wages were deductible to domestic businesses (and only domestic businesses) under the GIT, while tax was imposed on imports without a deduction for labor. The deduction for wages reduced the amount collected at the business level domestically with respect to a given sale relative to the amount collected on an import. The result is a tax on imports and imported inputs that appears to exceed the domestic tax on cash flow. This treatment can be viewed as facially affording protection to domestic production. ${ }^{10}$

Both of the earlier-described WTO compliance issues arose under the GIT. Conventional analysis has unnecessarily assumed that these issues are necessarily embedded in every possible version of a DBCFT.

\section{B. Exports}

The main WTO limitation on export supports arises out of the Agreement on Subsidies and Countervailing Measures (SCM). Article 1 of the SCM prohibits government financing from subsidizing exports, and provides that tax measures are subsidies if government revenue that is otherwise due is foregone or not collected. ${ }^{11}$

In addition, an "illustrative list" of export subsidies contained in the Appendix to the SCM provides that with respect to indirect taxes, the "exemption or remission, in respect of the production and distribution of exported products," must not be "in excess of those levied in respect of the production and distribution of like products when sold for domestic consumption."12 That "Illustrative List" also prohibits "full or partial exemption, remission, or deferral, specifically related to exports, of direct taxes."13

The GIT permitted exporters to deduct the value of both inputs and labor associated with export sales, without taking the sales into account in calculating taxable cash flow. As a result, it appears that the effective remission of tax would exceed the amount levied on the same good or service when sold for domestic consumption, because importers could not deduct the type of labor expense that was deductible by exporters. Separately, to the extent that the deduction of inputs and labor associated with export sales (or the tradability or refundability of net operating losses ("NOLs")) was considered a subsidy, foreign countries could argue that the GIT's border adjustment was impermissible because the deduction for labor would qualify the GIT as a "direct" tax.

Similar issues to those described earlier also arise under the text of Article XVI of the GATT (also covering the issue of subsidies). However, Article XVI of the GATT predates the SCM, and the General Interpretative Note to Annex 1A of GATT 1994 provides that to the extent of a conflict between Article XVI of the GATT and the SCM, the SCM prevails. ${ }^{14}$

${ }^{10}$ See also Hufbauer and $\mathrm{Lu}(2017)$.

${ }^{11}$ Agreement on Subsidies and Countervailing Measures annex V(4), April 15, 1994, Marrakesh Agreement Establishing the World Trade Organization, Annex 1A, Legal Instruments - Results of the Uruguay Round, available at http://www.wto.org/english/docs_e/legal_e/24-scm.pdf [hereinafter SCM Agreement].

${ }^{12}$ See Id. at Annex I (h).

${ }^{13} \mathrm{Id}$. at Annex I (e).

${ }^{14}$ See Multilateral Agreement on Trade in Goods, April 15, 1994, Marrakesh Agreement Establishing the World Trade Organization, Annex 1A, 1867 U.N.T.S. 187, 33 I.L.M 1153 (1994). This relationship between the SCM and Article XVI of the GATT is not always understood by tax academics. See, e.g., Schoen (2016). 
The SCM's Illustrative List was important in resolving the United States' most wellknown tax-related WTO disputes. Given the litigating history associated with the WTO disputes regarding the United States' Domestic International Sales Corporation (DSC), Foreign Sales Corporation (FSC), and Extraterritorial Income (ETI) tax regimes, U.S. analysts tend to jump directly to the "Illustrative List" of export subsidies contained in the Appendix of the SCM. ${ }^{15}$ They usually overlook the foundational requirement that revenue otherwise due be foregone in order for the Illustrative List to apply.

However, the SCM expressly provides that the "Illustrative List" of prohibited export subsidies only prohibits a tax measure to the extent that it constitutes a "subsidy" as defined by Article 1 of the SCM. Article III of the SCM prohibits specific measures, including those in the Illustrative List, to the extent that they constitute a subsidy. Thus the text of Article III provides in relevant part that "the following subsidies, within the meaning of Article 1 shall be prohibited" (emphasis added). The entire purpose of Article I is to define the term "subsidy." For a tax measure to be prohibited by the Illustrative List, it must first constitute a subsidy under Article I of the SCM. ${ }^{16}$

Determining whether a tax measure is a subsidy therefore first requires setting the baseline against which a determination will be made as to whether "government revenue that is otherwise due is foregone or not collected." ${ }^{\prime 17}$ As the WTO's Appellate Body pointed out in the FSC case:

"[T]he word 'foregone' suggests that the government has given up an entitlement to raise revenue that it could otherwise have raised. This cannot, however be an entitlement in the abstract, because governments, in theory, could tax all revenues. There must, therefore, be some defined normative benchmark against which a comparison can be made between the revenue actually raised and the revenue that would have been raised 'otherwise' ... ${ }^{18}$

\footnotetext{
${ }^{15}$ See, e.g., Lincicome and Eglin (2017). Indeed, as a young tax lawyer working on the Tax Reform Panel I made the same error a dozen years ago. See Grinberg (2006, pp. 929, 940).

${ }^{16}$ The alternative view would be that the CSM Illustrative List constitutes a per se subsidy list. However, this alternative view is largely rejected in the panel report from the FSC dispute. That panel report noted that "the use of a footnote to an item in the Illustrative List of Export Subsidies as context for the interpretation of Article 1 of the SCM Agreement poses certain interpretive problems. It is of course the case that the text of Article 1 must be read in its context, and that context includes the whole of the SCM Agreement (and, indeed, the WTO Agreement in its totality). That said, we consider that the degree to which a provision is relevant context and the weight to be given to a contextual element will differ from case to case, and may depend, inter alia, on the relationship between the provision being interpreted and the provision being relied upon as context. In this section of the Report, we are considering U.S. arguments regarding the interpretation of the definition of 'subsidy' as it appears in Article 1 of the SCM Agreement. Footnote 59, on the other hand, relates to the Illustrative List of Export Subsidies, and is obviously thus of greater relevance to determining when a measure is an export subsidy than to determining whether it is a subsidy as such." Report of the Panel, UNITED STATES - TAX TREATMENT FOR "FOREIGN SALES CORPORATIONS," WT/DS108/R, 7.90 (October 8, 1999).

${ }^{17}$ SCM Agreement, supra note 14, Article 1.

${ }^{18}$ Report of the Appellate Body, UNITED STATES - TAX TREATMENT FOR "FOREIGN SALES CORPORATIONS," WT/DS108/AB/RW, ๆ 87 (January 14, 2002).
} 


\section{ALTERNATIVE APPROACHES TO ADDRESS WTO CONCERNS}

The Blueprint was generally understood in the current public discourse to track the GIT in its approach to accomplishing border adjustments. However, in order to comply with our international obligations, a DBCFT should be drafted around the foundational WTO limitations on the treatment of imports and exports. Given the importance of the WTO's dispute resolution mechanism to the global trading system, WTO-compatibility should be sought after even if the limitations that arise in this context are largely formalistic.

Importantly, two alternative structural approaches to implementing a DBCFT could avoid foot faulting over the WTO's rules regarding facial discrimination with respect to imports and subsidies with respect to exports as described in Section II. The first structural alternative involves expanding the universe of businesses subject to a DBCFT by clearly defining both the base of the new U.S. business tax and its tax nexus requirement as domestic consumption, rather than imposing deduction disallowance or an import tax. I call this the "Greenprint." The second structural alternative involves adopting a business activities tax ${ }^{19}$ and then enacting a business-level incentive for encouraging employment that is as a legal matter separate from the tax rather than a deduction that is part of the tax. I call this the "Jobs Credit Plan." Either approach avoids the facial WTO law concerns raised by the 2005 GIT and the Blueprint.

\section{A. Greenprint}

The key features of the Greenprint drafting approach would be as follows:

1. All cash flow from sales of goods and services for use in the DBCFT-adopting country is taxable.

2. All cash flow from sales of goods and services for use outside the DBCFTadopting is non-includible.

Together these two principles would clearly define the tax base of the new business tax regime as encompassing all domestic consumption, and only domestic consumption. For ease of understanding, drafters would ideally place these basic rules at the opening of the statute, where their role at the heart of the regime would be most easily appreci-

${ }^{19}$ Senators Cruz and Paul each proposed a subtraction-method VAT during the 2016 presidential race. See http://www.aei.org/publication/another-proposal-for-a-hidden-vat/. Speaker Ryan supported a subtraction method VAT in 2009. See http://www.taxpolicycenter.org/taxvox/paul-ryans-consumption-tax. Representative Dick Armey (R-Texas) and his Senate co-sponsor Richard Shelby (R-Ala.) introduced a subtractionmethod VAT in 1995. H.R. 2060 and S. 1050 - The Freedom and Fairness Restoration Act (104th Cong. 1995), revision to H.R. 4585 (103rd Cong. 1994)). Senators Nunn and Domenici's Unlimited Savings Allowance ("USA") tax proposal from the mid-1990s imposed a modified subtraction-method VAT, with employers' share of payroll taxes treated as a credit against the VAT. USA Tax Act of 1995, S. 722, Sec. 201, 104th Cong., 1st Sess., 141 Cong. Rec. S5664 (1995). 
ated by lawyers unfamiliar with the law of the country adopting the tax. ${ }^{20}$ Legislative history and technical explanations would ideally further underscore the centrality of the concept of domestic consumption as the base of the new business taxation regime.

Carefully defining the base insulates the Greenprint from challenge under the WTO's rules regarding export subsidies. If the base of the tax is clearly domestic consumption, the exclusion of exports from cash flow is part of the defined normative benchmark of the tax. That exclusion does not and cannot represent revenue that is foregone or not collected. Thus, under WTO rules it should not matter whether the Greenprint is a "direct tax" or an "indirect tax."

After defining the base, the Greenprint would establish five other operative rules:

1. Each business that sells anything for use in the DBCFT-adopting country must file a DBCFT tax return in that country and "register" as a taxpayer. ${ }^{21}$

2. A deduction is available to all DBCFT taxpayers for all wages paid to taxpayers resident in the DBCFT-adopting country. Wages paid to nonresident aliens are nondeductible.

3. DBCFT taxpayers may deduct non-financial payments made to other DBCFT taxpayers.

4. Except for taxpayers organized in the DBCFT-adopting country, every business otherwise required to register as a DBCFT taxpayer may elect not to be a DBCFT taxpayer. Any taxpayer so electing would not be required to file a DBCFT tax return in the country for such taxable year. However, availing itself of this election requires the electing business to affirmatively forfeit the right to have purchases from that business be deductible for other DBCFT taxpayers.

5. DBCFT taxpayers are disallowed from taking deductions for payments made to entities that are not registered for DBCFT or do not file DBCFT returns. This last rule is needed for enforcement reasons, and should explicitly be characterized as an administrative principle.

As a result, under the Greenprint, imports are not treated differently than domesticallyproduced products, unless the seller (a) chooses to have them treated differently or (b) disregards domestic law (by failing to register or file a return). Allowing a foreign enterprise to elect to be treated differently than a national enterprise should not be a violation of national treatment. Indeed, the EU's regime for taxing the sale of all electronic services (as well as telecommunication and broadcasting services) relies on exactly such a mechanism: that regime mandates that all sellers with customers in the EU register to pay tax in the EU regardless of whether they maintain any physical presence in the

${ }^{20}$ Compare, e.g., American Health Care Act, H.R. 1628, 115th Cong. (1st Sess. 2017) (reflecting the other drafting approach common in U.S. legislative practice, involving emphasizing what is being modified in current law rather than what is being done).

${ }^{21}$ It is perhaps worth observing that this approach is analogous to the approach taken by Sec 11(a) of the current income tax. Sec 11(a) imposes tax on the taxable income of every corporation - not just domestic corporations. Section 11(d) then relieves some of that burden for foreign corporations. 
$\mathrm{EU}$, and then provides the option to choose a less-favorable but also less-burdensome regime. ${ }^{22}$ Like the EU regime, the Greenprint should not violate national treatment obligations under Article III of the GATT and Article XVII of the GATS.

More generally, a significant line of WTO cases consistently supports the conclusion that a tax regime is WTO-compliant if it treats domestically-produced and imported products similarly unless the importer fails to comply with defensible administrative rules. ${ }^{23}$ Most recently, in Argentina - Measures Related to Trade in Goods and Services, the WTO Appellate Body affirmed that treating certain transactions differently in order to ensure that foreign service suppliers are subject to taxation does not violate the GATS. ${ }^{24}$ Furthermore, the Appellate Body noted that the relevant provisions of the GATS and the GATT (Articles XIV(c) and XX(d), respectively) should be read consistently, such that the Argentina holding is also applicable to transactions in goods. Giving special tax treatment to transactions that fail to comply with domestic legal requirements that are not themselves inconsistent with WTO law is thus quite clearly permitted under Article XIV(c) of the GATS and Article XX(d) of the GATT. ${ }^{25}$

Opponents of the Greenprint might grant that while there is no formal legal discrimination in favor of domestic production under the Greenprint, the choice to provide a deduction for only domestic wages in effect constitutes a preference for domestic production. The claim would be that the decision to allow a deduction for domestic wages only is a violation of the principle of national treatment, even if that deduction is available to both domestic and foreign businesses, and exporters and importers alike. There would, however, be no credible argument that the Greenprint violates the national treatment principle on its face.

${ }^{22}$ See Council Implementing Regulation 282/2011, 2011 O.J. (L.77) 1, as amended by Council Regulation 967/2012, 2012 O.J. (L 290) 1, and Council Implementing Regulation 1042/2013, 2013 O.J. (L 284) 1.

${ }^{23}$ See, e.g., Report of the Panel, United States - Measures Affecting the Cross-Border Supply of Gambling and Betting Services, WT/DS285/R, (November 10, 2004), available at https://docs.wto.org/dol2fe/Pages/ FE_Search/FE_S_S009-DP.aspx?language $=$ E \&CatalogueIdList $=73463 \&$ CurrentCatalogueIdIndex $=0 \& F$ ullTextHash $=\&$ HasEnglishRecord $=$ True \&HasFrenchRecord=True\&HasSpanishRecord=True; Report of the Appellate Body, European Communities - Measures Prohibiting the Importation and Marketing of Seal Products, WT/DS400/AB/R WT/DS401/AB/R, (May 22, 2014), available at https://www.wto.org/ english/tratop_e/dispu_e/400_401abr_e.pdf.

${ }^{24}$ Report of the Appellate Body, Argentina - Measures Relating to Trade in Goods and Services, WT/DS453/ AB/R, \6.185 (April 14, 2016), available at https://www.wto.org/english/tratop_e/dispu_e/453abr_e.pdf (See generally 6.180-6.197); Report of the Panel, Argentina - Measures Relating to Trade in Goods and Services, WT/DS453/R, ๆ 7.637 (September 30, 2015), available at https://docs.wto.org/dol2fe/Pages/ FE_Search/FE_S_S009-DP.aspx?language $=$ E\&CatalogueIdList=134788,134790\&CurrentCatalogueIdIn de $=0 \&$ FullTextHash $=\&$ HasEnglishRecord $=$ True $\& H a s F r e n c h R e c o r d=$ True\&HasSpanishRecord $=$ True.

${ }^{25}$ Both Article XIV of the GATS and Article XX of the GATT 1994 affirm the right of Members to pursue various regulatory objectives even if, in doing so, Members act inconsistently with obligations set out in other provisions of the respective Agreements. General Agreement on Trade in Services art. XIV(c), 33 I.L.M. 1167, 1178 (1994); GATT art. XX(d), available at https://www.wto.org/english/res_e/booksp_e/ analytic_index_e/gatt1994_07_e.htm\#article20. See also Report of the Appellate Body, Korea - Measures Affecting Imports of Fresh, Chilled and Frozen Beef, WT/DS161/AB/R WT/DS169/AB/R, ๆ 157, (December 11, 2000); Report of the Appellate Body, Argentina - Measures Relating to Trade in Goods and Services, WT/DS453/AB/R, 6.113 (April 14, 2016). 
One necessary (although not sufficient) predicate for the argument that the Greenprint is in effect discriminatory would be credible economic analysis that the DBCFT affects competitive conditions between imported and domestic products. ${ }^{26}$ In the absence of facial discrimination, a showing of an effect on competitive conditions is needed to demonstrate that the legal rule being examined provides treatment to imported products that is less favorable than that provided to products of national origin. ${ }^{27}$ However, for

${ }^{26}$ See, e.g., Report of the Panel, United States - Measures Affecting Alcoholic and Malt Beverages, DS23/R — 39S/206, \ 5.6, (June 19, 1992), available at https://www.wto.org/english/tratop_e/dispu_e/91alcohm. pdf; Report of the Panel, United States - Taxes on Petroleum and Certain Imported Substances, L/6175 —34S/136. 9 5.1.9, (June 17, 1987), available at https://www.wto.org/english/tratop_e/dispu_e/87superf. pdf; Report of the Appellate Body, European Communities - Measures Prohibiting the Importation and Marketing of Seal Products, WT/DS400/AB/R WT/DS401/AB/R, ๆ 5.101, (May 22, 2014), available at https://www.wto.org/english/tratop_e/dispu_e/400_401abr_e.pdf (referring to Appellate Body Reports, United States - Clove Cigarettes, para. 179; China - Publications and Audiovisual Products, para. 305; Korea - Various Measures on Beef, para. 137; and Thailand - Cigarettes (Philippines), para. 128) (generally requiring a detrimental impact on the conditions of competition for like imported products in cases where facial discrimination is not evident). Separately, it should be noted that opponents of the Greenprint might make the superficial observation that the WTO's Appellate Body eventually found that predicating access to the ETI regime on a limit on the use of foreign inputs and foreign labor represented a violation of GATT Article III national treatment. They might argue that the inclusion of the "foreign labor" language in that ruling suggests that a denial of deductions for foreign labor violates Article III:4 of the GATT. However, the Appellate Body's ruling in the Article 21.5 proceedings was that the ETI rules requiring the use of U.S. inputs affected the "internal use" of imported products. Report of the Appellate Body, UNITED STATES - TAX TREATMENT FOR "FOREIGN SALES CORPORATIONS," WT/ DS108/AB/RW, 213 (January 14, 2002). Of course, no labor outside the United States is used internally to the United States. Thus, the ruling reached in the Article 21.5 proceeding is inapposite in considering the deduction for wages paid to U.S. residents at stake under the Greenprint. Indeed, considering the intent of Article III, it seems that disallowing a deduction for foreign labor should be permissible, as "[T]he intention of the drafters of the Agreement [GATT] was clearly to treat the imported products in the same way as the like domestic products once they had been cleared through customs." Italian Discrimination Against Imported Agricultural Machinery, BISD 7S/60, para. 11, quoted in Report of the Appellate Body, Japan — Taxes on Alcoholic Beverages, WT/DS8/AB/R WT/DS10/AB/R WT/DS11/AB/R, at 16 (October 4, 1996).

${ }^{27}$ At least one prominent tax academic has been inclined to analyze the compatibility of the DBCFT with Article III of the GATT by looking to the "legislative intent" of the DBCFT, including to determine whether border adjustments are a "natural" element of the "new paradigm" imposed by a DBCFT. See Schoen (2016). This approach to analyzing the meaning of Article III of the GATT (and somewhat analogous provisions in the GATS) was proposed by the European Union and rejected by the WTO Appellate Body two decades ago. See EC Bananas III, Appellate Body Report, WT/DS27/AB/R_, adopted 9 September 1997, para 241 (rejecting the alleged relevance of the so-called "aims-and-effects" test in the context of Article XVII of the GATS, and pointing out that the "aims and effects" test had previously been rejected in the context of Article III of the GATT, thereby clarifying that the policy purpose of a tax measure is not relevant to determining whether internal taxes or other internal charges of any kind are in excess of those applied to like domestic products). "We see no specific authority either in Article II or in Article XVII of the GATS for the proposition that the 'aims and effects' of a measure are in any way relevant in determining whether [a] measure is inconsistent with those provisions. In the GATT context, the 'aims and effects' theory had its origins in the principle of Article III:1 that internal taxes or charges or other regulations 'should not be applied to imported or domestic products so as to afford protection to domestic production'. There is no comparable provision in the GATS. Furthermore, in our Report in Japan - Alcoholic Beverages the Appellate Body rejected the 'aims and effects' theory with respect to Article III:2 of the GATT 1994." 
more than a generation, various of the world's leading public finance economists have written extensively that the border adjustment of a DBCFT would have no such effect on trade. ${ }^{28}$

Indeed, WTO rules already implicitly recognize the "no effect on competitive conditions" result for border adjustments to a DBCFT. WTO rules are clearly understood to permit countries to reduce corporate income taxes, replace the lost revenue with a value-added tax (VAT), and provide wage subsidies.

As many observers have noted over time, adopting a DBCFT in place of the corporate income tax would be economically equivalent to abandoning the corporate income tax, adopting a VAT, and adopting a wage subsidy. ${ }^{29}$ The standard economic analysis suggests that such a policy does have a pro-competitive effect, but not for the reason that imposing the cash flow tax changes competitive conditions. Rather, the pro-competitive effect comes from reducing the corporate income tax rate to zero. As is well-known, WTO rules place no limitation on countries reducing their corporate income tax rates.

\section{B. Jobs Credit Plan}

If a WTO challenge of the Greenprint remained a concern or, contrary to WTO precedent, a challenge of the Greenprint was sustained, it would be quite easy to move from the Greenprint to an equivalent system based on the Jobs Credit Plan. The Jobs Credit Plan generally produces the same economic results as the GIT or the Greenprint, with the same positive economic effects the House Blueprint emphasized. ${ }^{30}$

The Jobs Credit approach would involve adopting a business activities tax, ${ }^{31}$ and then enacting a business-level incentive for encouraging employment that is as a legal matter separate from the tax rather than a deduction that is part of the tax.

${ }^{28}$ See, e.g., Auerbach et al. (2017, pp. 18, 83); Bradford (2003, pp. 6-10); Devereux and de la Feria (2014, pp. 3-4, 9); Viard and Caroll (2012); Auerbach, Devereux, and Simpson (2010, pp. 884-886); Auerbach and Devereux (2017, pp. 19-21); Becker and Englisch (2017, p. 5); Auerbach and Holtz-Eakin (2016, pp. 5-7, 15); Lockwood (2001).

${ }^{29}$ See, e.g., Auerbach et al. (2017, pp. 18, 83).

${ }^{30}$ Alan Auerbach, et al. (2017, pp. 2, 16, 64-67) (describing the economic equivalence of a DBCFT and a VAT with a wage subsidy).

${ }^{31}$ Senator Cruz and Senator Paul both proposed a subtraction-method VAT during the 2016 presidential race. See http://www.aei.org/publication/another-proposal-for-a-hidden-vat/; Rep. Ryan supports a subtraction method VAT in 2009. See http://www.taxpolicycenter.org/taxvox/paul-ryans-consumption-tax; The Business Activities Tax endorsed by Senators Danforth (R) and Boren (D): The Comprehensive Tax Restructuring and Simplification Act of 1994, S. 2160, 103rd Cong. (1994) (introduced by Senator Danforth); Representative Dick Armey (R-Texas) and his Senate co-sponsor Richard Shelby (R-Ala.) introduced a subtraction-method VAT. H.R. 2060 and S. 1050 - The Freedom and Fairness Restoration Act (104th Cong . 1995), revision to H.R. 4585 (103rd Cong. 1994); Tax Foundation discussion of subtraction-method VATs in history. https:// files.taxfoundation.org/legacy/docs/42ba0b679274b3f8e7649b04827aa1b2.pdf; see also Danforth and Boren (1994); Massa III (1994). Senators Nunn and Domenici's Unlimited Savings Allowance ("USA") tax proposal from the mid-1990s imposed a modified subtraction-method VAT, with employers' share of payroll taxes treated as a credit against the VAT. USA Tax Act of 1995, S. 722, Sec. 201, 104th Cong., 1st Sess., 141 Cong. Rec. S5664 (1995). 
The tax component of this alternative proposal is indisputably a border-adjustable consumption tax. Moreover, the business-level incentive is technically separate from the tax code. Thus, under the WTO's formalistic rules, which consider wage subsidies and tax provisions separately, there is no "export subsidy" for a direct tax, no "national treatment" violation for imports, and no "excessive" border adjustment of an indirect tax.

WTO rules provide that subsidies outside the income tax system that are intended, in the words of the WTO "generally to sustain employment" and are provided to both domestic and foreign companies are "important instruments for the promotion of social and economic policy objectives. ${ }^{32}$ They are explicitly blessed as a legitimate tool of government policy by the WTO. This blessing holds even though such payments are economically equivalent to tax deductions when provided at the value of the deduction multiplied by the tax rate.

\section{Features of the Jobs Credit Plan}

\section{Business Activities Tax}

Registered businesses would assess a standard subtraction-method VAT. Deductions would be available to the same extent that they are made available in the Greenprint, except that labor expenses would not be deductible.

\section{Business-Level Tax Credit}

DBCFT taxpayers would receive a refundable credit that would be netted against both payroll and DBCFT liability. This "Jobs Credit" would be based on the amount of wages and compensation paid by DBCFT taxpayers to workers residing in the DBCFTadopting country. ${ }^{33}$ The credit would equal the business tax rate times the total wages a business paid to qualifying workers. It would be available to all DBCFT taxpayers in all industries, regardless of whether the business was a domestic or foreign entity.

As a practical matter, the jobs credit could be treated as accruing as qualifying wages are paid. Thus, in any country with a tax administrative architecture similar to that of the United States, it could be taken into account on a quarterly basis when employers make both payroll tax deposits and estimated DBCFT payments. ${ }^{34}$

32 Agreement on Interpretation and Application of Articles VI, XVI and XXIII of the General Agreement on Tariffs and Trade, GATT Doc. MTN/NTM/W/236 (1973), available at https://www.wto.org/english/ docs_e/legal_e/tokyo_scm_e.pdf.

${ }^{33}$ Qualifying individuals could be either U.S. or foreign nationals. The requirement would be that they be resident in the United States and pay tax to the United States on their earned income.

${ }^{34}$ Noncontroversial guidance and procedures adopted in connection with a modest refundable employerside payroll tax credit enacted as part of the American Recovery and Reinvestment Act of 2009 indicate that the AJC is administratively workable, at least in the United States. See Internal Revenue Service, COBRA: Questions and Answers for Employers; I.R.S. Notice 2009-27, 2009-16 I.R.B. 838 (2009). Code section 6432 was enacted to provide for an employer subsidy of COBRA premiums for involuntarily terminated employees. Assistance-eligible individuals are only required to pay 35 percent of their COBRA premiums, with the remaining 65 percent of the COBRA premium paid by employers and reimbursed 


\section{Wage Tax}

Current payroll taxes at the individual level help complete the architecture. They ensure that even loss-making companies have some positive liability against which the jobs credit may be offset.

One would expect the economic incidence of the jobs credit approach to be similar to the economic incidence of a DBCFT. The move from a deduction at the business level to a credit at the business level should not affect incidence under standard theoretical models. Each business (and each group of wage earners) makes the same net payment to the government under the Jobs Credit Plan as they would under the subtractionmethod cash flow tax with a wage deduction. Thus, just as the deduction for wages in a progressive subtraction-method VAT should benefit labor, so should the jobs credit, which is tied to wages paid.

\section{Border Tax Adjustments Would be Permissible}

The Jobs Credit Plan should be WTO-compliant. To begin with, the plain vanilla subtraction-method VAT component of the Jobs Credit Plan should be border adjustable by definition. WTO agreements and reports specifically conclude that the value-added tax is an "indirect" and therefore border-adjustable tax. ${ }^{35}$ As for the payroll tax, it is not subject to any WTO rules.

Moreover, as discussed earlier, the SCM defines the term "subsidy" to include provisions pursuant to which "government revenue that is otherwise due is foregone or not collected (e.g., fiscal incentives such as tax credits)." ${ }^{36}$ However, the SCM explicitly permits subsidies based on objective criteria that are capable of verification and are not limited to specific enterprises or categories of enterprises, contingent on export performance, or contingent on using domestic rather than imported inputs. ${ }^{37}$ The type of subsidy that is prohibited is a subsidy that is contingent on export performance or which requires the use of domestic rather than imported goods. ${ }^{38}$

to the employer by means of a payroll tax credit available through quarterly payroll tax return filings on Form 941, with refunds available to employers in any instance in which credits exceed payroll tax withholding liability. American Recovery and Reinvestment Act of 2009, P.L. 111-5, Sec. 3001 (2009).

35 SCM, supra note 14, at Annex I(g). The 1970 GATT Working Party Report on Border Tax Adjustments also concluded that indirect taxes were limited to taxes "directly levied on products." GATT Working Party Report, at para. 14. Report by the Working Party, Border Tax Adjustments, L/3464 (Nov. 20, 1970), at 9 14, available at https://www.wto.org/gatt_docs/English/SULPDF/90840088.pdf.

${ }^{36} I d$. at art. 1.1(a)(1)(ii).

${ }^{37}$ Id. at art. 2.1(a) (subsidies explicitly limited to certain enterprises are "specific"); art. 2.1(b) (defining objective criteria for a subsidy); art. 3 (subsidies may not be contingent on export performance, using domestic rather than imported inputs, or be "specific"). Use or predominant use of a subsidy program by a limited number of enterprises, or by enterprises limited to a designated geographical region, and the manner in which any discretion is exercised by the granting authority may also make a subsidy a prohibited "specific" subsidy. Id. at art. 2.1(c).

${ }^{38} \mathrm{Id}$. at art. 3.1. 
Indeed, in the Tokyo Round of Agreements with respect to the GATT, signatories agreed that subsidies (other than export subsidies) paid domestically and intended "generally to sustain employment" were permitted as they were "important instruments for the promotion of social and economic policy objectives." ${ }^{39}$

Applying these criteria, a business-level wage credit would seem to be permissible. The jobs credit is not contingent on export performance or the use of domestic over imported goods. Eligibility for the jobs credit would be automatic and available to all domestic-owned and foreign-owned DBCFT taxpayers on exactly the same basis regardless of the type of business or industry. The credit would be available to registered businesses regardless of whether the relevant workers are domestic or foreign citizens, so long as the worker pays domestic individual-level tax. Thus, the jobs credit meets the requirements for a permissible subsidy under WTO rules.

The border adjustments associated with the Jobs Credit Plan also should not be susceptible to challenge on the grounds that they provide an "exemption or remission" of tax in excess of the tax imposed on like products when sold for domestic consumption. Again, the jobs credit sits formally outside the indirect tax system. If the WTO were to disregard the separation of the jobs credit from the tax system (treating the jobs credit like a subtraction-method deduction), then the result would be that any national wagesubsidy program - of the sort maintained by most EU countries - would be impermissible under WTO rules. ${ }^{40}$ When combined with a border adjustment of the VAT, these wage subsidy programs clearly produce an overall tax plus wage subsidy net rebate on exported products. Yet they are not considered analogous to an excess remission of tax, and indeed have been explicitly blessed as WTO-permissible, in part because they are not export-dependent. ${ }^{41}$ Accordingly, the Jobs Credit Plan, which similarly provides a wage subsidy without regard to exportation, should also be border-adjustable.

${ }^{39}$ GATT, Agreement on Interpretation and Application of Articles VI, XVI, and XXIII of the General Agreement on Tariffs and Trade (September 12, 1973).

${ }^{40}$ The vast majority of the member states of the EU use governmental hiring subsidies. These counties include Belgium, Denmark, Germany, Estonia, Ireland, Greece, Spain, France, Croatia, Italy, Latvia, Lithuania, Luxembourg, Hungary, Malta, the Netherlands, Austria, Poland, Portugal, Romania, Slovenia, Slovakia, Sweden, and the United Kingdom. See European Commission (2014, pp. 18-19). For example, in Italy, the Ministry of Labour and Social Policies and the Ministry of the Economy and Finance has adopted the Interministerial Decree 243/2012 establishing a fund that provides financial support for the employment of young people and women. $I d$. at 16-17. The United Kingdom maintains a wage subsidy program paid to employers that provides up to 2,275 GBP for full-time work per month for six months when hiring covered young people. $I d$. at 20 . Germany has implemented wage subsidies for older workers aged 50 and above and an integration wage subsidy voucher. Recruitment of older workers can be subsidized for 12 to 36 months (those unemployed below 50 years of age can be subsidized for only 12 months). The subsidy level ranges between 30 and 50 percent of wages. Id. at 22.

${ }^{41}$ GATT historically resisted explicitly addressing labor policies. For example, the U.S. request to link flexible labor rules and free trade in a ministers' declaration made at the time of formation of the WTO was rebuffed. Riding, Adam, "U.S. Gains a Trade Forum for Labor-Equity Issues," New York Times, April 8, 1994, p. D6. Further, when linkages were explored, the question was whether labor standards and wage supports were sufficiently high, and not whether a country was providing excessive wage supports (Alben, 2001). 
The Jobs Credit Plan is thus another tool that policymakers can use to make a DBCFT WTO-compatible. The case for jobs credit compatibility with WTO rules is strong, and other national governments use business-level wage subsidies for various purposes without ever having faced a WTO challenge. Indeed, many countries would be concerned with a WTO challenge of a jobs credit system. The jobs credit system has the additional advantage of easily interacting with other tax systems around the world, without sacrificing best practice cash flow tax design features that allow for effective enforcement.

\section{LESSONS FOR BUSINESS TAX REFORM}

In our modern globalized economy, business tax policy is inextricably linked to crossborder trade and investment. As a result, national tax policy should be implemented with an eye on WTO and other treaty commitments.

At the same time, the international tax system is changing worldwide, and shifting towards a greater focus on source and destination-based taxation. As a result, even if domestic policymaking stagnates, the international tax environment around the world will continue to evolve, and is likely to become increasingly less favorable to resident business in countries with high traditional corporate income tax rates.

The Base Erosion and Profit Shifting (BEPS) Project at the Organisation for Economic Co-operation and Development (OECD) was justified as an attempt to prevent the old, largely favorable framework for international taxation from falling apart and being replaced by unilateral actions, double taxation of cross-border business income, and what the OECD termed "global tax chaos." Unfortunately, the post-BEPS environment already shows signs of becoming characterized by much of the global tax chaos the BEPS Project was supposed to prevent. Countries around the world are unilaterally shifting to more destination-based tax regimes and increasingly disregarding prior international tax norms. As business tax policymakers work - as they should - to respond to these trends, they should keep an eye on the interaction between tax law and other fields of international law.

The good news is that by carefully studying WTO rules, tax policymakers can preserve policy flexibility without violating international law commitments. WTO issues need not and should not be determinative in choosing a sensible approach to business tax reform. Multiple options exist to make a DBCFT border-adjustable.

\section{ACKNOWLEDGMENTS}

I thank Christopher Brown and Federico Parrada Larrosa for able research assistance, Grant Aldonas and Jennifer Hillman for helpful discussions, and Steve Cohen for comments on an earlier draft. Any errors are my own.

\section{DISCLOSURES}

The author had no financial arrangements that gave rise to conflicts of interest with respect to the research reported in this paper. 


\section{REFERENCES}

Alben, Elissa, 2001. "GATT and the Fair Wage: A Historical Perspective on the Labor-Trade Link.” Columbia Law Review 101 (6), 1410-1447.

Auerbach, Alan J., and Michael P. Devereux, 2017. "Cash-Flow Taxes in an International Setting.” Econometrics Laboratory, University of California, Berkeley, http://eml.berkeley.edu/ auerbach/ Auerbach\%20Devereux\%202-25-17.pdf.

Auerbach, Alan J., Michael Devereux, Michael Keen, and John Vella, 2017. "Destination-Based Cash Flow Taxation." Oxford University Centre for Business Taxation Working Paper No. 17/01. Oxford University Centre for Business Taxation, Oxford, UK, http://www.sbs.ox.ac.uk/sites/ default/files/Business_Taxation/Docs/Publications/Working_Papers/Series_17/WP1701b.pdf.

Auerbach, Alan J., Michael P. Devereux, and Helen Simpson, 2010. "Taxing Corporate Income." In Mirrlees, James, et al. (Ed.), Dimensions of Tax Design, 884-886. Oxford University Press, Oxford, UK.

Auerbach, Alan J., and Douglas Holtz-Eakin, 2016. "The Role of Border Adjustments in International Taxation.” Econometrics Laboratory, University of California, Berkeley, https:// eml.berkeley.edu/ auerbach/The\%20Role \%20of\%20Border\%20Adjustments\%20in\%20 International\%20Taxation\%2012-2-16-1.pdf.

Becker, Johannes, and Joachim Englisch, 2017. "A European Perspective on the US Plans for a Destination Based Cash Flow Tax." Oxford University Centre for Business Taxation Working Paper No. 17/03. Oxford University Centre for Business Taxation, Oxford, UK, http://www.sbs. ox.ac.uk/sites/default/files/Business_Taxation/Docs/Publications/Working_Papers/Series_17/ WP1703.pdf.

Bradford, David F., 2003. "The X Tax in the World Economy." CEPS Working Paper No. 93. Centre for European Policy Studies, Brussels, Belgium, https://www.princeton.edu/ceps/ workingpapers/93bradford.pdf.

Danforth, John C., and David L. Boren, 1994. "The Comprehensive Tax Restructuring and Simplification Act of 1994: Technical Overview.” Tax Notes Today 94 (May 27), 103-126.

Devereux, Michael, and Rita de la Feria, 2014. "Designing and Implementing a DestinationBased Corporate Tax." Oxford University Centre for Business Taxation Working Paper No. 14/07. Oxford University Centre for Business Taxation, Oxford, UK, http://eureka.sbs.ox.ac. uk/5081/1/WP1407.pdf.

Eizenstat, Stuart, John Veroneau, and James Smith, 2010. "WTO-Consistency of Legislation to Disallow Deductions for Excess Reinsurance Premiums Paid to Affiliates." Covington \& Burling LLP, http://www.coalitionforamericaninsurance.com/wp-content/uploads/2017/06/ CovingtonOpinion.pdf.

European Commission, European Employment Policy Observatory Review, 2014. Stimulating Job Demand: The Design of Effective Hiring Subsidies in Europe 2014. ISSN 1977-4478, 18-19, ec.europa.eu/social/BlobServlet?docId=11950\&langID=en. 
Grinberg, Itai, 2006. "Implementing a Progressive Consumption Tax: Advantages of Adopting the VAT Credit-Method System.” National Tax Journal 59 (4), 929-954.

Hufbauer, Gary Clyde, and Zhiyah (Lucy) Lu, 2017. "Border Tax Adjustments: Assessing Risks and Rewards." PIIE Policy Brief No. 17-3. Peterson Institute for International Economics, Washington, DC, https://piie.com/system/files/documents/pb17-3.pdf.

Lincicome, Scott, and Richard Eglin, 2017. "Border-Adjustable Taxes under the WTO Agreements.” White \& Case Publications \& Events, White \& Case, https://www.whitecase.com/ publications/alert/border-adjustable-taxes-under-wto-agreements.

Lockwood, Ben, 2001. "Tax Competition and Tax Co-ordination under Destination and Origin Principles: A Synthesis." Journal of Public Economics 81 (2), 279-319.

Massa III, Cliff, 1994. “The ‘Business Activities Tax’_A Primer.” Tax Notes 64 (August 29), 1219.

Schoen, Wolfgang, 2016. "Destination-Based Income Taxation and WTO Law: A Note." Working Paper of the Max Planck Institute for Tax Law and Public Finance No. 2016-3. Munich, Germany, https://papers.ssrn.com/sol3/papers.cfm?abstract_id=2727628.

Viard, Alan D., and Caroll, Robert 2012. Progressive Consumption Taxation: The X-Tax Revisited. AEI Press, Washington DC. 